\title{
Produksi Inulinase Pichia alni DUCC-W4 pada Tepung Umbi Dahlia (Dahlia variabilis Willd) dengan Variasi Konsentrasi Ammonium Nitrat dan Waktu Inkubasi
}

\author{
Wijanarka, Rejeki Siti Ferniah dan Salamah \\ Lab. Mikrobiogenetika Jurusan Biologi FMIPA UNDIP
}

\begin{abstract}
Abstrak
Inulinase (E.C.3.2.1.7) merupakan kelompok enzim hidrolase yang mampu menghidrolisis inulin menjadi fruktosa. Produksi fruktosa secara langsung dari inulin oleh enzim inulinase hanya memerlukan satu tahap reaksi enzimatis dan menghasilkan $90 \%$ fruktosa sehingga lebih efisien. Optimasi perlu dilakukan untuk meningkatkan produksi inulinase, antara lain dengan penambahan sumber nitrogen dan optimasi waktu inkubasi. Khamir merupakan salah satu mikroba yang dapat memproduksi enzim. Salah satu khamir inulinolitik yang berhasil diisolasi dari umbi dahlia yaitu Pichia alni DUCC-W4. Tujuan penelitian ini adalah mengetahui variasi konsentrasi $\mathrm{NH}_{4} \mathrm{NO}_{3}$ dan waktu inkubasi Pichia alni DUCC-W4 dalam memproduksi inulinase pada tepung umbi dahlia. Penelitian ini dilaksanakan di laboratorium mikrobiologi, Jurusan Biologi Fakultas MIPA Universitas Diponegoro. Penentuan aktivitas inulinase dilakukan dengan metode DNS. Penelitian ini menggunakan Rancangan Acak Lengkap (RAL) faktorial dengan 2 faktor. Faktor I (P0, P1, P2, dan P3) berupa konsentrasi $\mathrm{NH}_{4} \mathrm{NO}_{3}$ yang berbeda yaitu 0,029mM; 0,05 mM; 0,1 mM; 0,15 mM dan faktor II (H1, H2, dan H3) berupa waktu inkubasi (12 jam,18 jam, dan 24 jam). Masing - masing perlakuan diulang sebanyak 3 kali. Data yang diperoleh dianalisis dengan menggunakan metode ANOVA. Aktivitas inulinase masing - masing perlakuan pada waktu inkubasi 12 jam yaitu $0,567 \mathrm{U} / \mathrm{mL}, 0,407$ $\mathrm{U} / \mathrm{mL}, 0,304 \mathrm{U} / \mathrm{mL}, 0,486 \mathrm{U} / \mathrm{mL}$, pada waktu inkubasi 18 jam yaitu $0,761 \mathrm{U} / \mathrm{mL}, 0,644 \mathrm{U} / \mathrm{mL}, 0,543 \mathrm{U} / \mathrm{mL}, 0,554$ $\mathrm{U} / \mathrm{mL}$, sedangkan waktu inkubasi 24 jam yaitu $0,564 \mathrm{U} / \mathrm{mL}, 0,567 \mathrm{U} / \mathrm{mL}, 0,529 \mathrm{U} / \mathrm{mL}, 0,612 \mathrm{U} / \mathrm{mL}$. Berdasarkan hasil penelitian menunjukkan bahwa penambahan konsentrasi $\mathrm{NH}_{4} \mathrm{NO}_{3}$ pada medium produksi dan perbedaan waktu inkubasi tidak meningkatkan aktivitas inulinase Pichia alni DUCC-W4.
\end{abstract}

Kata kunci : umbi dahlia, Pichia alni DUCC-W4, inulinase, $\mathrm{NH}_{4} \mathrm{NO}_{3}$

\section{PENDAHULUAN}

Ketergantungan manusia pada gula sangat tinggi, ini tercermin dari produksi gula nasional yang belum dapat memenuhi tingkat konsumsi gula di Indonesia. Sampai saat ini, Indonesia masih mengimpor gula karena ketidakseimbangan permintaan dan produksi gula nasional akibat terbatasnya lahan yang cocok untuk perkebunan tebu dan tingginya biaya produksi (Tjokroadikoesoemo, 1986). Keadaan inilah yang mendorong upaya mencari aneka jenis bahan untuk digunakan sebagai pemanis, sehingga banyak diproduksi pemanis alternatif. Salah satu alternatif yang digunakan sebagai pemanis alami adalah fruktosa (Wijanarka, dkk., 2006b).

Produksi fruktosa secara konvensional dari molekul pati memerlukan paling sedikit tiga tahap reaksi enzimatis menggunakan enzim $\alpha$-amilase, amiloglukosidase, dan invertase. Rendemen fruktosa yang dihasilkan dari cara ini sekitar $45 \%$. Produksi fruktosa secara langsung dari inulin oleh enzim inulinase dapat menghasilkan $90 \%$ fruktosa (Gupta, et.al., 1990; Saryono, dkk, 1999).

Menurut Xiao et al. (1988) inulin merupakan salah satu bahan baku potensial dalam pembuatan HFS (High Fructose Syrup = sirup fruktosa). Inulin adalah senyawa karbohidrat alamiah yang merupakan polimer dari unit-unit fruktosa. Polisakarida ini dapat dihasilkan oleh beberapa tanaman umbi-umbian (seperti pada dahlia, Jerusalem artichoke dan chicory) dan berperan sebagai karbohidrat cadangan (Gupta, et.al., 1990). Umbi dahlia mengandung 69,50 $75,48 \%$ inulin, yang berpotensi untuk dihidrolisis menjadi sirup fruktosa dan fruktooligosakarida atau sebagai substrat pada produksi alkohol secara fermentasi (Saryono, dkk, 1999; Allais, et.al., 1986).

Inulinase (E.C.3.2.1.7) adalah enzim hidrolitik yang mengkatalisis reaksi hidrolisis polisakarida inulin menjadi fruktosa dan atau fruktooligosakarida. Dibandingkan dengan sumber 
enzim lain seperti dari tumbuhan atau hewan, mikrobia diketahui lebih potensial sebagai penghasil enzim. Hal ini disebabkan pertumbuhan mikrobia yang relatif cepat (Crueger \& Crueger, 1984). Menurut Wijanarka dkk (2006a) salah satu khamir inulinolitik yang berhasil diisolasi dari umbi dahlia yaitu Pichia alni DUCC-W4.

Khamir membutuhkan nutrien untuk kehidupannya. Peran utama nutrien adalah sebagai sumber energi, selain itu juga untuk memproduksi enzim. Salah satu sumber nutrien adalah nitrogen yang dapat digunakan dalam bentuk organik maupun anorganik (Waluyo, 2004). Nutrien yang dipakai dalam penelitian ini adalah ammonium nitrat $\left(\mathrm{NH}_{4} \mathrm{NO}_{3}\right)$. Ammonium nitrat merupakan sumber nitrogen anorganik yang mengandung $34,5 \%$ nitrogen, mudah dibuat di laboratorium dengan mereaksikan asam nitrat dengan ammonia berair (Anonim, 2006). Beberapa penelitian telah dilakukan untuk meningkatkan produksi enzim inulinase, tetapi belum ada penelitian yang mendukung tentang penggunaan ammonium nitrat untuk meningkatkan produksi inulinase oleh Pichia alni DUCC-W4. Sumber nitrogen ini dapat digunakan untuk pembentukan asam amino dan protein.

\section{BAHAN DAN METODE}

Bahan. Pichia alni DUCC-W4 koleksi dari Wijanarka, dkk (2006a), tepung umbi dahlia (Dahlia variabilis Willd.), inulin murni, sukrosa, $\left(\mathrm{NH}_{4}\right)_{2} \mathrm{HPO}_{4}, \mathrm{NH}_{4} \mathrm{NO}_{3}$, medium PDA (Potato Dextrose Agar), $\mathrm{MgSO}_{4} .7 \mathrm{H}_{2} \mathrm{O}$, yeast extract, asam dinitrosalisilat, sodium potassium tartrat, $\mathrm{NaOH}$, dan akuades.

Pembuatan Tepung Umbi Dahlia. Umbi dahlia yang sudah dicuci bersih dikupas, dipotong kecilkecil dan dikeringkan dalam oven suhu $80^{\circ} \mathrm{C}$. Umbi dahlia yang sudah kering selanjutnya digiling sampai menjadi tepung.

Pembuatan Medium Produksi Inulinase. Tepung umbi dahlia sebanyak $3 \mathrm{~g}$ dalam $100 \mathrm{~mL}$ aquades dipanaskan selama 25 menit, disaring dan selanjutnya ditambahkan dengan $0,23 \mathrm{~g} \mathrm{NH}_{4} \mathrm{NO}_{3}$; $0,37 \mathrm{~g}\left(\mathrm{NH}_{4}\right)_{2} \cdot \mathrm{HPO}_{4} ; 0,1 \mathrm{~g} \mathrm{~K}_{2} \mathrm{HPO}_{4} ; 0,05 \mathrm{~g}$ $\mathrm{MgSO}_{4} \cdot 7 \mathrm{H}_{2} \mathrm{O}$, dan $0,15 \mathrm{~g}$ yeast extract pada $\mathrm{pH} 5$, disterilisasi dengan autoklaf pada suhu $121^{\circ} \mathrm{C} 2$ atm selama 15 menit.
Pembuatan Starter. Satu ose isolat khamir Pichia alni DUCC-W4 dinokulasikan ke dalam medium produksi steril, kemudian diagitasi dengan rotary shaker berkecepatan $150 \mathrm{rpm}$ pada suhu ruang selama 22 jam (T $27 \%$ ) sehingga didapatkan kultur dengan kepadatan $10^{7} \mathrm{sel} / \mathrm{mL}$.

Pertumbuhan sel. Kultur dari starter diambil sebanyak $10 \% \quad(\mathrm{v} / \mathrm{v})$ dan diinokulasikan pada masing-masing medium produksi dengan berbagai konsentrasi $\mathrm{NH}_{4} \mathrm{NO}_{3}$, yaitu $0,029 \mathrm{mM}$ (P0), $0,05 \mathrm{mM}(\mathrm{P} 1) ; 0,1 \mathrm{mM}(\mathrm{P} 2)$ dan $0,15 \mathrm{mM}(\mathrm{P} 3)$, kemudian diagitasi dengan rotary shaker berkecepatan $150 \mathrm{rpm}$ pada suhu ruang. Pengambilan kultur dilakukan setiap 6 jam untuk mengukur pertumbuhan sel secara langsung dengan metode turbidimetri. Pertumbuhan sel ditentukan dengan mengukur nilai optical density (OD) menggunakan spektrofotometer pada $\lambda_{520}$ nm. Pengukuran pertumbuhan merupakan penelitian pendahuluan untuk menentukan waktu inkubasi yang dipilih dalam uji aktivitas enzim.

Produksi Enzim. Produksi enzim inulinase dilakukan dengan cara starter diambil sebanyak $10 \%$ (v/v) dan diinokulasikan pada masing-masing medium produksi dengan berbagai konsentrasi $\mathrm{NH}_{4} \mathrm{NO}_{3}$ yaitu $0,029 \mathrm{mM}(\mathrm{P} 0), 0,05 \mathrm{mM}(\mathrm{P} 1) ; 0,1$ $\mathrm{mM}(\mathrm{P} 2)$ dan $0,15 \mathrm{mM}(\mathrm{P} 3)$, kemudian diagitasi dengan rotary shaker berkecepatan $150 \mathrm{rpm}$ pada suhu ruang. Pemanenan enzim dilakukan dengan cara pengambilan kultur pada jam ke-12, 18 dan 24. Sampel kultur yang diambil disentrifugasi pada kecepatan 3000 rpm selama 10 menit. Supernatan yang diperoleh merupakan crude enzim dan digunakan untuk uji aktivitas enzim

Pengukuran Aktivitas Enzim (Xiao, et. al., 1998; Wijanarka dkk., 2006a). Pengukuran aktivitas enzim meliputi aktivitas inulinase dan invertase sehingga akan diketahui rasio I/S. Aktivitas inulinase dan invertase dianalisis dengan metode DNS (Chaplin and Kennedy, 1994) dan ditentukan berdasarkan sejumlah $1 \mu$ mol gula reduksi yang dibebaskan per menit pada kondisi tertentu. Gula reduksi diukur dengan cara menghitung absorbansi enzim substrat (ES) dikurangi dengan absorbansi substrat (S) dan enzim (E), sehingga diperoleh rumus sebagai berikut : 
Aktivitas Enzim $=$

$$
\frac{(A b s E S-A b s S-A b s E) \text { fruktosa }}{B M \times 30^{\prime}} \times \mathrm{P} \times 1000
$$

Keterangan : Abs ES = absorbansi enzim substrat, Abs $\mathrm{E}=$ absorbansi enzim, Abs $\mathrm{S}=$ absorbansi substrat, $\mathrm{BM}=$ berat molekul fruktosa $(180,1), \mathrm{P}=$ faktor pengenceran.

\section{Aktivitas Inulinase}

Penentuan aktivitas inulinase dilakukan dengan cara menyiapkan 3 tabung untuk diisi campuran yang berbeda. Tabung pertama (ES) berisi $0,9 \mathrm{~mL}$ campuran substrat inulin dan buffer dan $0,1 \mathrm{~mL}$ crude enzim. Tabung kedua (S) berisi $0,9 \mathrm{~mL}$ campuran substrat inulin dan buffer dan $0,1 \mathrm{~mL}$ akuades. Tabung ketiga (E) berisi 0,4 $\mathrm{mL}$ buffer; $0,1 \mathrm{~mL}$ crude enzim dan $0,5 \mathrm{~mL}$ akuades. Satu tabung sebagai blangko diisi 0,4 $\mathrm{mL}$ buffer dan $0,6 \mathrm{~mL}$ akuades.

Masing-masing tabung diinkubasi selama 30 menit pada suhu $50^{\circ} \mathrm{C}$. Reaksi dihentikan dengan memasukkan tabung sampel ke dalam air mendidih selama 5 menit dan setelah dingin ditambahkan reagen DNS (Lampiran 12) sebanyak $1 \mathrm{~mL}$. Selanjutnya dipanaskan ke dalam air mendidih selama 10 menit dan setelah dingin ditambahkan dengan $5 \mathrm{~mL}$ akuades. Setiap sampel larutan diukur absorbansinya dengan spektrofotometer pada $\lambda_{570} \mathrm{~nm}$. Aktivitas inulinase ditentukan berdasarkan sejumlah $1 \mu \mathrm{mol}$ gula reduksi yang dibebaskan per menit pada kondisi tertentu.

\section{Aktivitas Invertase}

Penentuan aktivitas invertase dilakukan sama seperti pada penentuan aktivitas inulinase, hanya saja yang berbeda adalah substratnya. Substrat yang digunakan adalah larutan sukrosa $1 \%$.

Rancangan Percobaan dan Analisis Data. Penelitian ini menggunakan Rancangan Acak Lengkap faktorial dengan 2 faktor yang dicoba yaitu faktor I (P0, P1, P2, dan P3) berupa konsentrasi $\mathrm{NH}_{4} \mathrm{NO}_{3}$ yang berbeda yaitu 0,029 $\mathrm{mM} 0,05 \mathrm{mM}, 0,1 \mathrm{mM}, 0,15 \mathrm{mM}$ dan faktor II (H1, $\mathrm{H} 2$, dan $\mathrm{H} 3$ ) berupa waktu inkubasi (12 jam,18 jam, dan 24 jam). Kedua faktor ini diperlakukan pada medium produksi inulinase Pichia alni DUCC-W4. Masing - masing percobaan diulang sebanyak tiga kali. Data yang diperoleh dilakukan uji homogenitas varian dengan uji Barlett dan uji normalitas dengan uji komolghorov - Smirnov. Data yang normal dan varian homogen dianalisis dengan Analysis of Varian (Sugandi dan Sugiarto, 1994; Steel and Torrie,1995; Hanafiah, 2000).

\section{HASIL DAN PEMBAHASAN}

Pertumbuhan khamir pada medium produksi dengan penambahan $\mathrm{NH}_{4} \mathrm{NO}_{3}$ pada berbagai konsentrasi menunjukkan kecenderungan pola yang sama (Gambar 1). Pertumbuhan tertinggi terlihat pada waktu inkubasi 24 jam terutama pada perlakuan ketiga dengan penambahan $\mathrm{NH}_{4} \mathrm{NO}_{3} \quad 0,15 \mathrm{Mm}$. Pertumbuhan khamir dipengaruhi oleh adanya nutrien dalam medium, salah satunya yaitu sumber nitrogen. Menurut Brock et. al. (1994), sumber nitrogen tersebut akan digunakan khamir untuk pembentukan protein dan asam amino yang akan membantu pertumbuhannya.

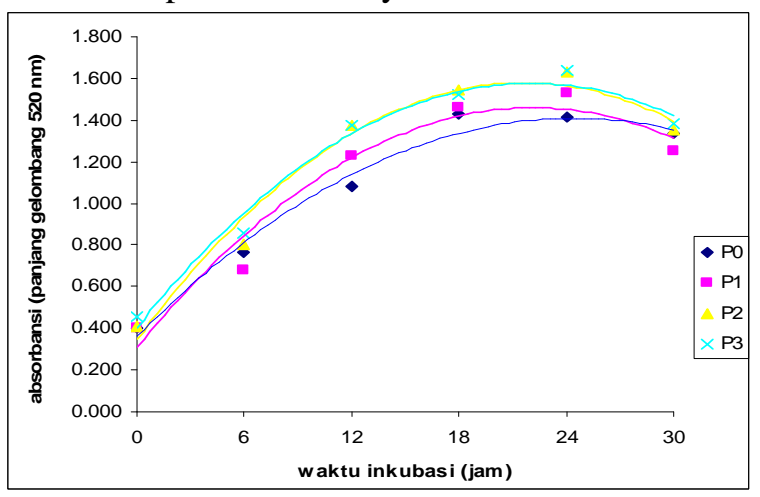

Gambar 1. Kurva pertumbuhan Pichia alni DUCC-W4 dalam medium produksi dengan penambahan $\mathrm{NH}_{4} \mathrm{NO}_{3}$ pada berbagai konsentrasi selama waktu inkubasi 30 jam.

Keterangan : $\mathrm{P} 0$ : $0,029 \mathrm{mM} \mathrm{NH} \mathrm{NHO}_{3}$ dalam medium basal, P1 : 0,05 $\mathrm{mM} \mathrm{NH}_{4} \mathrm{NO}_{3}, \mathrm{P} 2: 0,1$ $\mathrm{mM} \mathrm{NH}_{4} \mathrm{NO}_{3}, \mathrm{P} 3: 0,15 \mathrm{mM} \mathrm{NH}_{4} \mathrm{NO}_{3}$.

Berdasarkan Gambar .1 menunjukkan bahwa pertumbuhan tertinggi terjadi pada waktu inkubasi $12-24$ jam. Hasil ini menjadi dasar untuk perhitungan produksi enzim karena aktivitas enzim mengalami peningkatan seiring dengan laju pertumbuhan (growth assosiated). Menurut Brock et.al. (1994), enzim digolongkan menjadi 
metabolit primer yang biasanya dibentuk pada fase pertumbuhan logaritmik. Pertumbuhan sel akan terjadi sangat cepat dan enzim mulai dihasilkan meningkat pada fase logaritmik. Jadi, aktivitas enzim yang akan diuji yaitu pada waktu inkubasi $12(\mathrm{H} 1), 18(\mathrm{H} 2)$, dan $24(\mathrm{H} 3)$.

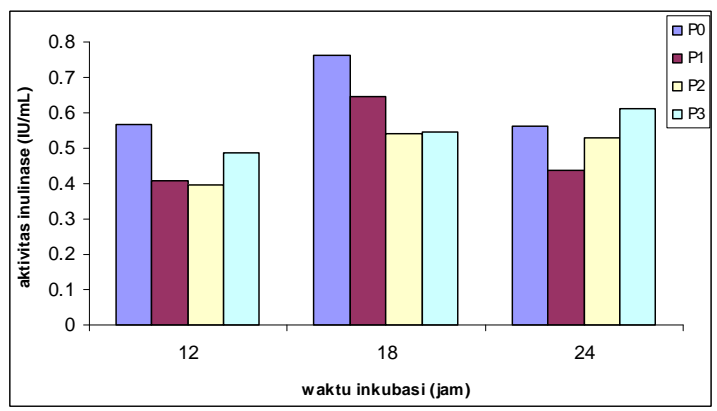

Gambar 2. Histogram aktivitas inulinase Pichia alni DUCC-W4 dalam medium produksi dengan penambahan $\mathrm{NH}_{4} \mathrm{NO}_{3}$ pada berbagai konsentrasi dan waktu inkubasi yang berbeda, masing masing menunjukkan hasil yang berbeda tidak nyata setelah dianalisis dengan ANOVA.

Keterangan : P0 : 0,029 mM $\mathrm{NH}_{4} \mathrm{NO}_{3}$ dalam medium basal, $\quad \mathrm{P} 1: 0,05 \mathrm{mM} \mathrm{NH}_{4} \mathrm{NO}_{3}, \mathrm{P} 2$ : $0,1 \mathrm{mM} \mathrm{NH}_{4} \mathrm{NO}_{3}, \quad \mathrm{P} 3: 0,15 \mathrm{mM} \mathrm{NH}_{4} \mathrm{NO}_{3}$.

Gambar 2 menunjukkan bahwa pada waktu inkubasi 18 jam aktivitas inulinase pada perlakuan berturut - turut yaitu $0,761 \mathrm{U} / \mathrm{mL}, 0,644$ $\mathrm{U} / \mathrm{mL}, 0,543 \mathrm{U} / \mathrm{mL}, 0,612 \mathrm{U} / \mathrm{mL}$. Berdasarkan hasil analisis sidik ragam menunjukkaan bahwa tidak ada perbedaan yang nyata pada aktivitas inulinase antar perlakuan. Jadi penambahan $\mathrm{NH}_{4} \mathrm{NO}_{3}$ 0,5 mM, 0,1 mM, 0,15 mM pada Pichia alni DUCC-W4 tidak berpengaruh nyata pada produksi inulinasenya. Penelitian Xiao et.al. (1988) menunjukkan bahwa penambahan konsentrasi $\mathrm{NH}_{4} \mathrm{NO}_{3} \quad 0,1 \quad \mathrm{M}$ sebagai sumber nitrogen pada kapang Chrysosporium pannorum juga tidak memberikan pengaruh yang simultan. Sumber $\mathrm{N}$ yang mampu meningkatkan aktivitas inulinase dilaporkan oleh Skowronek \& Fiedurek (2004) dengan menggunakan $\mathrm{NaNO}_{3}$ 0,73 \%, namun ini dijumpai pada kapang Aspergillus niger.

Tidak adanya perbedaan yang nyata pada aktivitas inulinase antar perlakuan menunjukkan tidak ada pengaruh penambahan $\mathrm{NH}_{4} \mathrm{NO}_{3}$ bagi peningkatan aktivitas inulinase. Salah satu hal yang diduga menyebabkan penambahan $\mathrm{NH}_{4} \mathrm{NO}_{3}$ tidak mempengaruhi aktivitas inulinase Pichia alni DUCC-W4 karena konsentrasi $\mathrm{NH}_{4} \mathrm{NO}_{3}$ yang digunakan dalam penelitian ini kemungkinan lebih banyak digunakan untuk mendukung proses pertumbuhan ataupun untuk protein struktural pembentukan organela dalam sel. Kemungkinan juga karena sumber nitrogen yang digunakan dalam penelitian ini tidak hanya $\mathrm{NH}_{4} \mathrm{NO}_{3}$ saja, sehingga mungkin terjadi kelebihan sumber nitrogen. Kondisi ini menyebabkan penambahan $\mathrm{NH}_{4} \mathrm{NO}_{3} \quad 0,5 \mathrm{mM}, 0,1 \mathrm{mM}, 0,15 \mathrm{mM}$ dalam medium kurang efektif sehingga tidak meningkatkan produksi inulinase secara signifikan.

Hasil analisis sidik ragam juga menunjukkan bahwa pengaruh waktu inkubasi 12 , 18 dan 24 jam berbeda tidak nyata. Hal ini menunjukkan bahwa waktu inkubasi juga tidak mempengaruhi aktivitas atau produksi inulinase. Menurut Brock et.al. (1994), pada fase logaritmik, pertumbuhan sel akan terjadi sangat cepat dan produksi enzim meningkat. Produksi enzim terus terjadi pada saat fase stasioner, sehingga pada jam ke 12, 18, dan 24 produksi inulinase juga masih relatif stabil. Sintesis inulinase akan menurun setelah fase stasioner karena jumlah nutrisi dalam medium yang semakin berkurang dan sel mengalami fase kematian. Dapat diasumsikan bahwa waktu yang efisien untuk produksi inulinase dalam penelitian ini adalah jam ke - 12 .

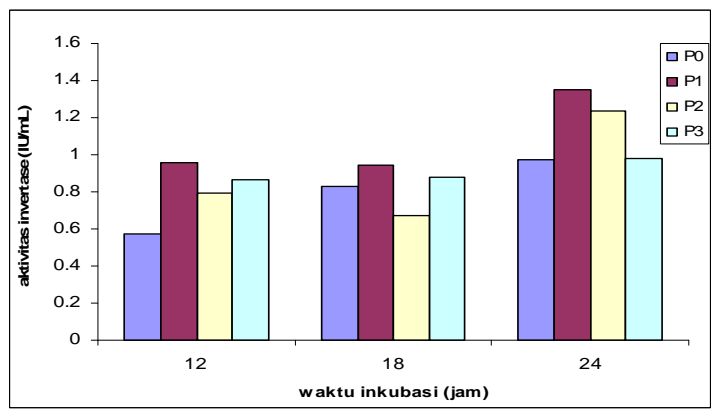

Gambar 3. Histogram aktivitas invertase Pichia alni DUCC-W4 dalam medium produksi dengan penambahan $\mathrm{NH}_{4} \mathrm{NO}_{3}$ pada berbagai konsentrasi dan waktu inkubasi yang berbeda. 
Keterangan : P0 : 0,029 mM $\mathrm{NH}_{4} \mathrm{NO}_{3}$ dalam medium basal, $\quad \mathrm{P} 1: 0,05 \mathrm{mM} \mathrm{NH}_{4} \mathrm{NO}_{3}, \mathrm{P} 2$ : $0,1 \mathrm{mM} \mathrm{NH}_{4} \mathrm{NO}_{3}, \quad$ P3 : $0,15 \mathrm{mM} \mathrm{NH}_{4} \mathrm{NO}_{3}$.

Berdasarkan hasil analisis sidik ragam dari aktivitas invertase menunjukkaan bahwa tidak ada perbedaan yang nyata pada aktivitas inulinase antar perlakuan. Hal ini menunjukkan tidak ada pengaruh penambahan $\mathrm{NH}_{4} \mathrm{NO}_{3}$ bagi peningkatan aktivitas invertase. Hasil analisis sidik ragam juga menunjukkan bahwa pengaruh waktu inkubasi 12, 18 dan 24 jam berbeda tidak nyata. Hal ini menunjukkan bahwa waktu inkubasi juga tidak mempengaruhi aktivitas atau produksi invertase.

Menurut Ertan et.al. (2003) adanya aktivitas invertase yang mengiringi aktivitas inulinase dapat digunakan untuk mengetahui rasio I/S atau S/I (I : inulinase, S : invertase). Rasio I/S ini digunakan untuk mengetahui aktivitas katalitik enzim. Semakin besar nilai rasio I/S maka aktivitas inulinasenya juga besar.

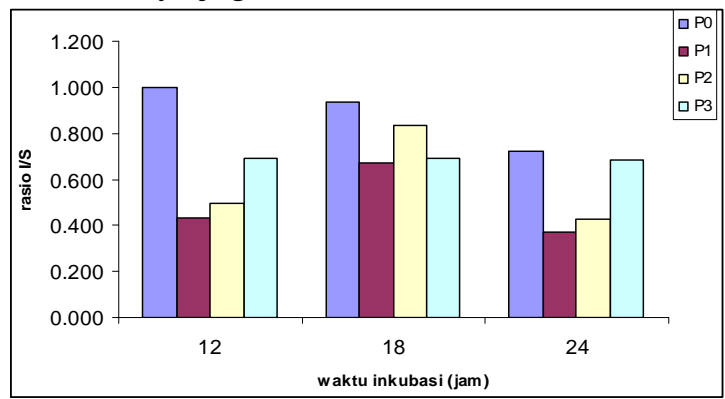

Gambar 4. Histogram Rasio I/S Pichia alni DUCC-W4 dalam medium produksi dengan penambahan $\mathrm{NH}_{4} \mathrm{NO}_{3}$ pada berbagai konsentrasi dan waktu inkubasi yang berbeda.

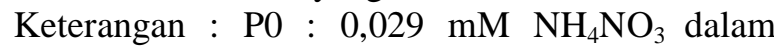
medium basal, $\quad \mathrm{P} 1: 0,05 \mathrm{mM} \mathrm{NH}_{4} \mathrm{NO}_{3}, \mathrm{P} 2$ : $0,1 \mathrm{mM} \mathrm{NH}_{4} \mathrm{NO}_{3}, \mathrm{P} 3: 0,15 \mathrm{mM} \mathrm{NH}_{4} \mathrm{NO}_{3}$.

Berdasarkan hasil analisis sidik ragam dari rasio I/S menunjukkan bahwa tidak ada perbedaan yang nyata pada rasio I/S antar perlakuan (Lampiran 10). Hal ini menunjukkan tidak ada pengaruh penambahan $\mathrm{NH}_{4} \mathrm{NO}_{3}$ bagi peningkatan rasio I/S. Hasil analisis sidik ragam juga menunjukkan bahwa pengaruh waktu inkubasi 12 , 18 dan 24 jam berbeda tidak nyata (Lampiran 10). Hal ini menunjukkan bahwa waktu inkubasi juga tidak mempengaruhi rasio $\mathrm{I} / \mathrm{S}$. Hal ini dikarenakan penambahan $\mathrm{NH}_{4} \mathrm{NO}_{3}$ pada medium tidak berpengaruh terhadap aktivitas inulinase maupun invertase sehingga nilai rasio I/S yang didapatkan menunjukkan nilai yang bebeda tidak nyata pula.

\section{KESIMPULAN}

Bedasarkan hasil penelitian yang telah dilakukan, maka dapat diambil kesimpulan bahwa penambahan konsentrasi $\mathrm{NH}_{4} \mathrm{NO}_{3}$ pada medium produksi pada konsentrasi $0,05 \mathrm{mM}, 0,1 \mathrm{mM}$, dan $0,15 \mathrm{mM}$ dan perbedaan waktu inkubasi tidak mempengaruhi aktivitas inulinase Pichia alni DUCC-W4.

\section{UCAPAN TERIMA KASIH}

Penulis mengucapkan banyak terima kasih kepada Kementerian Riset dan Teknologi yang telah membiaya Penelitian ini Tahun Anggaran 2007 No.99 / RT / Insentif / PPK/ I / 2007.

\section{DAFTAR PUSTAKA}

Allais, J.J., G. Hoyos-Lopez, S. Kammoun And J. Baratti. !986. Isolation and Characterization of ThermoPhilic Bacterial Strain With Inulinase Activity. Appl. Environ. Microbial. 53 (5) : 942-945.

Anonim. 2002. Ammonium Nitrate. http://www.uneptie.org/pc/apell/disasters/tou louse/nh4no3.html. 14 Okrober 2006 . 2004a. Dahlia, Cantik Bunganya, Manis umbinya.

http://kukun10.blogspot.com/2004/08/dahlia -cantik-bunganya-manisumbinya.htlm. 19 Oktober 2006 2004b. The Taxonomicon

http;//www.taxonomy.ni/Taxonimicon/taxon Tree.aspx?id=193791.

7 Oktober 2006.

.2006. Ammonium Nitrate. http://en.wikipedia.org/wiki/Ammonium nit rate. 14 Oktober 2006

Brock, T. D.,Madigan, M. T., Martinko, J. M., and Parker, J. 1994. Biology of Microorganism. $5^{\text {th }}$ Edition. Prentice-Hall, Inc., Englewood Cliffs New Jersey, USA.

Byun, S. M. and B. H. Nahm. 1978. Production of Fructose from Jerussalem Aartichoke by 
Enzymatic Hydrolysis. J. of Food Science. $43 ; 1871-1873$.

Chaplin, M. F. and J. F. Kennedy. 1994.Carbohydrat Analysis: A Practical Approach. $2^{\text {nd }}$ Edition. Oxford University Press. Oxford.

Crueger, W and Crueger, A. 1984. Biotechnology: A Text Book of Industrial Microbiology. Science Tech., Inc., Madison. Wisconsin.

Ertan, F., T. Aktac, A. C. Kaboglu, F. Ekinci and E. Bakar. 2003. Determination of Optimum Cultivation Conditions on The Production of Inulinase from Rhizoctonia solani. Pak. J. of Biosci. 6 (16): 1386-1388.

Fardiaz, S. 1992. Mikrobiologi Pangan. Pusat Antar universitas Pangan Gizi. Bogor.

Gupta, A. K., P. Rathore, N. Kaur and R. Singh. 1990. Production Therma Stability and Immobilization of Inulinase of Fusarium oxysporum. J. Chem. Tech. Biotech. P: 245251.

Hanafiah, K. A. 2000. Rancangan Percobaan : Teori dan Aplikasi. PT. Raja Grafindo Persada, Jakarta.

Kalil, S. J., Suzan, R., Maugeri, F, and Rodrigues, M. I. 2001. Optimization of Inulinase Production by Kluyveromyces marxianus Using Factorial Design. Appl. Biochem. Biotech. Abstrak

Barboza, M., Maugeri, F., and Rodrigues, M. I. 2006. Studies on The Adsorption of Inulinase from Kluyveromyces marxianus ATCC 16045 onto an Ion Exchange Resin. Braz. J. Food. Technol. 9(3) : $223-228$.

Kuswanto, K.R. \& S. Sudarmadji. 1988. Prosesproses Mikrobiologi Pangan. Universitas Gadjah Mada. Yogyakarta.

McGregor. 1998. Yeast. Biotech and Bioanal. Barkeley. California.

Montgomery, D. C. 1984. Design and Analysis of Experiment. Second Edition. John Wiley \& Sons, New York.

Murray, R. K., D. K. Granner., V. W. Rodwell., David W. M.. 2000. Biokimia Harper. Terjemahan: dr. Andry Hartono. Penerbit Buku Kedokteran EGC, Jakarta.
Nakamura, T.,Nagatomo, Y., Hamada, S., Nishino, Y., and Ohta, K. 1994. Occurance of Two forms of Extracellular Endoinulinase from Aspergillus niger mutant 817. J. Ferment. Bioeng. $78: 134-139$.

Pelczar and Chan. 1986. Dasar - dasar Mikrobiologi. Terjemahan: Hadioetomo, R. S, Imas, T, Tjitrosomo, S. S, Angka, S. Penerbit Universitas Indonesia, Jakarta.

Ram, A. 2006. What Does The Filamentous Fungus Aspergillus niger Eat for Lunch?. Spotlight Seminar, 5 October 2006.

Rouwenhorst, R. J., L. E. Visser, A. A van Derban , W.A Scheffer and J. p. van Dikjen. 1990. Production, Distribution and Kinetic Properties of Inulinase in Continous Culture Kluyveromyces sp. Appl. Environ. Microbial. 54(5): 1131-1137.

Rukmana, R. 2000. Dahlia: Prospek Agribisnis dan Teknik Budidaya. Penerbit Kanisius. Yogyakarta.

Saryono, A., M. Chainulfiffah, D. S. Silvera, H. S. Monalisa dan Dasli. 1998. Pemanfaatan Umbi Dahlia (Dahlia variabilis) untuk Produksi Sirup Fruktosa (HFS) dan Fruktooligosakarida. Seminar Nasional PBBMI XIV. Bandung.

Skowronek, M, Kuszewska, J., Fiedurek, J. and Gramada, A. 2003. Invertase Activity of Psychrotrophic Fungi. Annales Universitatis Mariae Curie-Sklodowska. Lublin - polania. $19: 20-23$. and J. Fiederuk. 2005. Purification and Properties of Extracelluler Endoinulinase from Aspergillus niger 20 OSM. Food Technol. Biotechol. 44 (1) : 5358.

Steel, R. G. D and Torrie, J. H. 1995. Prinsip dan Prosedur Satistika : Suatu Pendekatan Biometrik. PT. Gramedia Pustaka Utama, Jakarta.

Sugandi, E and Sugiarto. 1994. Rancangan Percobaan : Teori dan Aplikasi. Andi Offset, Yogyakarta.

Synder, H. E and Phaff, H. J. 1962. The Pattern of Action of Inulinase from Saccharomyces fragilis on Inulin. The Journal of Biological Chemistry. 237 (8) : 2438-2441. 
Tjitrosoepomo, G.1996. Taksonomi Tumbuhan. UGM press. Yogyakarta.

Tjokroadikoesoema, P. S. 1986. HFS dan Industri Ubi Kayu Lainnya. Penerbit PT. Gramedia, Jakarta.

Vandame, E. J. and D. G. Derycke. 1983. Microbial Inulinase: Fermentation Process, Properties and Application. Advances in Appl. Microbial. 29: 139-176.

Walker, G. m. 1997. Yeast Physiology and Biotechnology. John Wiley and Sons. Chichster.

Waluyo, 1. 2004. Mikrobiologi Umum. UMM Press. Malang.

Widowati, S., Sunarti, T. C., dan Zaharani, A. 2005. Ekstraksi, Karakterisasi, dan Kajian Potensi Prebiotik Inulin dari Umbi Dahlia (Dahlia pinnata L.). Seminar Rutin Puslitbang Tanaman Pangan, Bogor. 1 -12. 2006. Dahlia Bunganya Indah, Umbinya Mengandung Inulin. Sinar Tani Edisi $19-25$ april 2006.

Wijanarka, E. Kusdiyantini dan H. Pancasakti. 2006a. Paket Teknologi Eksplorasi Khamir Inulinolitik Thermostabil Umbi Dahlia (Dahlia variabilismWilld) Jawa Tengah melalui Teknik Fusi Protoplas dan
Aplikasinya pada Produksi High Fructose Syrup (HFS). Laporan Hasil pelaksanaan Penelitian Hibah Bersaing Perguruan Tinggi XIV/I Tahun Anggaran 2006.

_. 2006b. Fusi Protoplas Interspesifik Khamir Inulinolitik Termostabil Kluyveromyces Marxianus dan Torulospora Pretoriensis Isolat Lokal serta Aplikasinya pada Produksi High Fructose Syrup (HFS). Laporan Hasil pelaksanaan Penelitian Hibah Bersaing Perguruan Tinggi XIV/I Tahun Anggaran 2006.

Xiao, R., M. Tanida and S. Takao. 1988. Inulinase from Crysosporium pannorum. J. Ferment. Technol. 66 (5): 244-248.

1989.

Purification and Some Properties of Endo Inulinase from Crysosporium pannorum. $J$. Ferment.Bioeng. 67 (4): 244. 